\title{
Landscape Online
}

\section{Swiss Tree Lines - a GIS-Based Approximation}

\section{Erich Szerencsits}

\author{
Agroscope Reckenholz-Tänikon Research Station ART, Agricultural Landscapes and \\ Biodiversity, Reckenholzstrasse 191; CH-8046 Zürich; +41 (0)44 377 7469, +41 (0)44 377 7111, \\ Erich.Szerencsits@art.admin.ch
}

\begin{abstract}
Mountain timber lines are relevant in the context of land abandonment and climate change. For Switzerland, GIS-compliant delimitations of the tree line and the forest line are still lacking. Recent high-resolution landcover information offers new possibilities for GIS-based approaches. In a Swiss-wide study, an analysis based on slope zones was combined with a moving-window analysis to assess tree and forest line altitude, using topographic data. The tree and the forest lines were delimited at the upper altitude reached by a tree or closed forest respectively. The model delivered a fine-scaled delimitation sensitive to local conditions. The results indicate that earlier studies underestimated the tree line altitudes for the fringes of the Alps. Also the variability inside climatic and bio-geographical regions is larger than it was estimated up to now.
\end{abstract}

\section{Keywords}

forest line, Geographic Information System, GIS, moving-window analysis, reforestation, Switzerland, tree line 


\section{Introduction}

$\mathrm{T}$ he timber line is advancing upwards. But where is it now? Imhof (1900), Brockmann-Jerosch (1919), Landolt (1984), and Eggenberg (2002) published isolines indicating the regional maximum altitude of trees and forest for the Swiss Alps. The mapping units of the Swiss Flora include a coarse boundary of the alpine vegetation zone (Welten \& Sutter 1982; Wohlgemuth 1993). Schmid (1961) mapped the vegetation types of Switzerland. Despite all these efforts, a detailed, GIScompliant delimitation of the tree and forest lines is still lacking. Recent high-resolution land-cover information offers new possibilities for GIS-based approaches.

The mountain timber line is a significant boundary for both landscape perception and environmental conditions (Wardle 1974; Burga et al. 2004). In fact it is not simply a line but a transition zone between two more or less well-defined boundaries (Holtmeier 2009): The forest line in a narrow interpretation is the upper limit of closed forest. Above the timber line ecotone, the tree line indicates the highest elevation sustaining trees and defines the boundary between the subalpine and the alpine vegetation zone. Close to the tree line, rates of tree growth decrease dramatically (Körner 2003).

The tree line and the forest line are determined by climatic and pedologic conditions and they are lowered by forest clearings, agricultural use, microclimate and natural disturbance (Ellenberg 1986; Holtmeier \& Broll 2007; Kruckeberg 2002; Wieser \& Tausz 2007). Swiss valleys are cultural landscapes with a long history. They have been populated for centuries and in many cases, the upper mountain slopes were colonised earlier than the valley bottoms (Bätzing 2005). Therefore, on a local scale, there are often significant gaps between the potential and the current tree and forest lines.

Land abandonment is the main driving force for the establishment of new forest areas, even close to the tree line (Gehrig-Fasel et al. 2007). Comparing two surveys of the Swiss land cover statistic (Arealstatistik) 1979-1985 and 1992-1997 (BFS 1985; BFS 2001), $29.6 \%$ of the newly forested area in Switzerland was previously summer-grazing area (Hotz \& Weibel 2005). Because subalpine landscapes are hot spots for species-rich grassland, the reforestation of mountain grassland can contribute significantly to biodiversity loss (Dirnböck et al. 2003, Dullinger et al. 2003). In Switzerland, around $80 \%$ of high-biodiversity-value habitats are located in mountain areas (Baur et al. 2006) and approximately $60 \%(\sim 250,000 \mathrm{ha})$ of the summer grazing area is located below the potential tree line (Mack et al. 2008). Besides their ecological importance, cultivated open mountain landscapes play a vital role by attracting tourism (Hunziker 1995). This has implications for the development and implementation of agri-environmental measures to limit the reforestation in the mountain regions(Fig. 1). In 2009, the Swiss government proposed allocating direct payments to farmers for maintaining landscape quality (BBL 2009). The tree line is considered to be a significant boundary for their spatial implementation.

When measuring tree line and forest line altitude, one has to cope with the numerous definitions of tree and forest adopted in different studies and datasets (Ellenberg 1986; Holtmeier 2009). Imhof (1900) had used the Topographic Atlas 1:50,000 of Switzerland (Swisstopo 2011) to measure the forest line altitude and he had argued that the mapping of forest has been done very carefully because of its strong strategic and economic significance. According to his study on the Swiss Topographic Map 1:25,000, Eggenberg (2002) pointed at inconsistencies between the definition of the map signatures and the tree formations in question. The Topographic Map 1:25,000, which is the source of the Vector 25 dataset, was designed for orientation and navigation in the field and therefore generalised. The major requirements were the perception in the field and the readability of the resulting map. Another Swiss wide land-cover dataset is Arealstatistik (BFS 2001). Compared to Vector25 it uses a narrow interpretation of closed forest. In contrast to automatically classified remote sensing data, the visual photo interpretation of Arealstatistik yielded highly reliable datasets. The disadvantage in the context of this study is that it was carried out on sample points located on a regular 100 x $100 \mathrm{~m}$ grid. Finally, GIS analyses depend on the availability of the base data and hence on the tree and forest definition used for the respective survey.

The objective of this study was to approximate the tree line and the forest line for the whole of Switzerland based on topographic data. The lines were delimited at the upper altitude reached by a tree or closed forest respectively. With regard to practical application the 


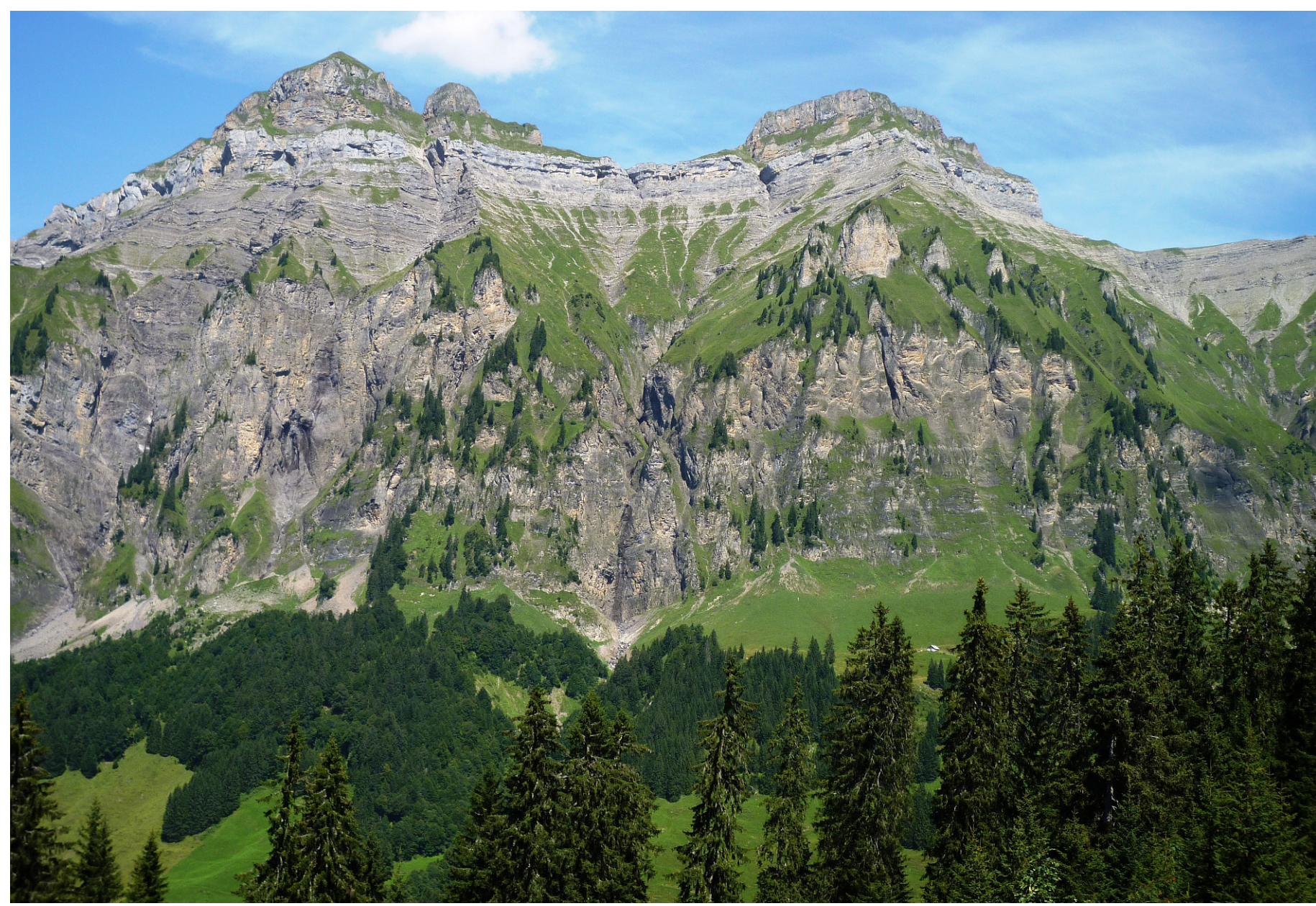

Figure 1. The photo shows the southern face of Druesberg in the northern Swiss Alps (2282 m, Muotathal). On inaccessible areas of the valley slopes, trees approximate the upper tree line. The forest boundaries are shaped by agriculture. A few decades ago, hay harvesting even on the steepest slopes (Wildheu) was essential for the subsistence of the local people. Now subsidies help to sustain the cultural heritage.

results should approximate the potential tree and forest line altitudes but respect local site conditions. This paper details the methodological approach and presents the results. Additional analyses were performed to quantify the impact of the two combined approaches on the delimitation and to estimate the plausibility of the results.

\section{Methods}

\subsection{Study area, spatial resolution, and software}

The study was carried out for the whole of 1 Switzerland $\left(41,293 \mathrm{~km}^{2}\right)$. Intermediate results of the analyses are presented for the example of Niesen ridge (Figs. 3, 5, and 6).

As the resolution of the digital elevation model is
$25 \times 25$ metres, this grid size was adopted for raster modelling. Considering the raster resolution and the spatial accuracy of the topographic data the geometric error was expected to be less than 50 metres. A map scale $1: 50,000$ is considered to be suitable to display the results.

The model was implemented in the Geographic Information System ArcGIS 9.31 and the extension Spatial Analyst using Model Builder.

\subsection{Data}

A fine-grained land-cover data set was required for A the study. The topographic database Vector25 (Swisstopo 2009) provides primary surfaces, water bodies, infrastructure, linear and point features. The features are based on the topographic map in a scale 
of 1:25,000. Trees are defined with a minimum height of 3 metres. Closed forest has an extent of more than $30 \mathrm{~m}$ and a canopy cover of more than 50 percent. The accuracy is within three to eight metres. The data cover Switzerland and the surrounding area.

The land-cover dataset Arealstatistik 1992-1997 (BFS 2001 ) is the result of a stereoscopic image interpretation performed on aerial photographs taken between 1992 and 1997. It provides 74 land-cover classes. Trees are defined with a minimum height of 3 metres. Normal dense forest is defined by an extent of $50 \mathrm{~m}$ and a canopy cover of 60 percent. Arealstatistik sample points are located on a regular grid with a mesh size of
$100 \times 100$ metres. The data cover Switzerland.

Relief information is provided by DHM25, a digital elevation model with a resolution of $25 \times 25$ metres (Swisstopo 2001). The average accuracy of spot height is three metres for the Swiss Alps. The data cover Switzerland and the surrounding area.

The hydrographical classification (BWG \& GIUB 2001) divides Switzerland into 1081 catchment areas with sizes between $30-50 \mathrm{~km}^{2}$. They were used as basic edges for the spatial reference units since the catchment areas represent the shape of the valley slopes.

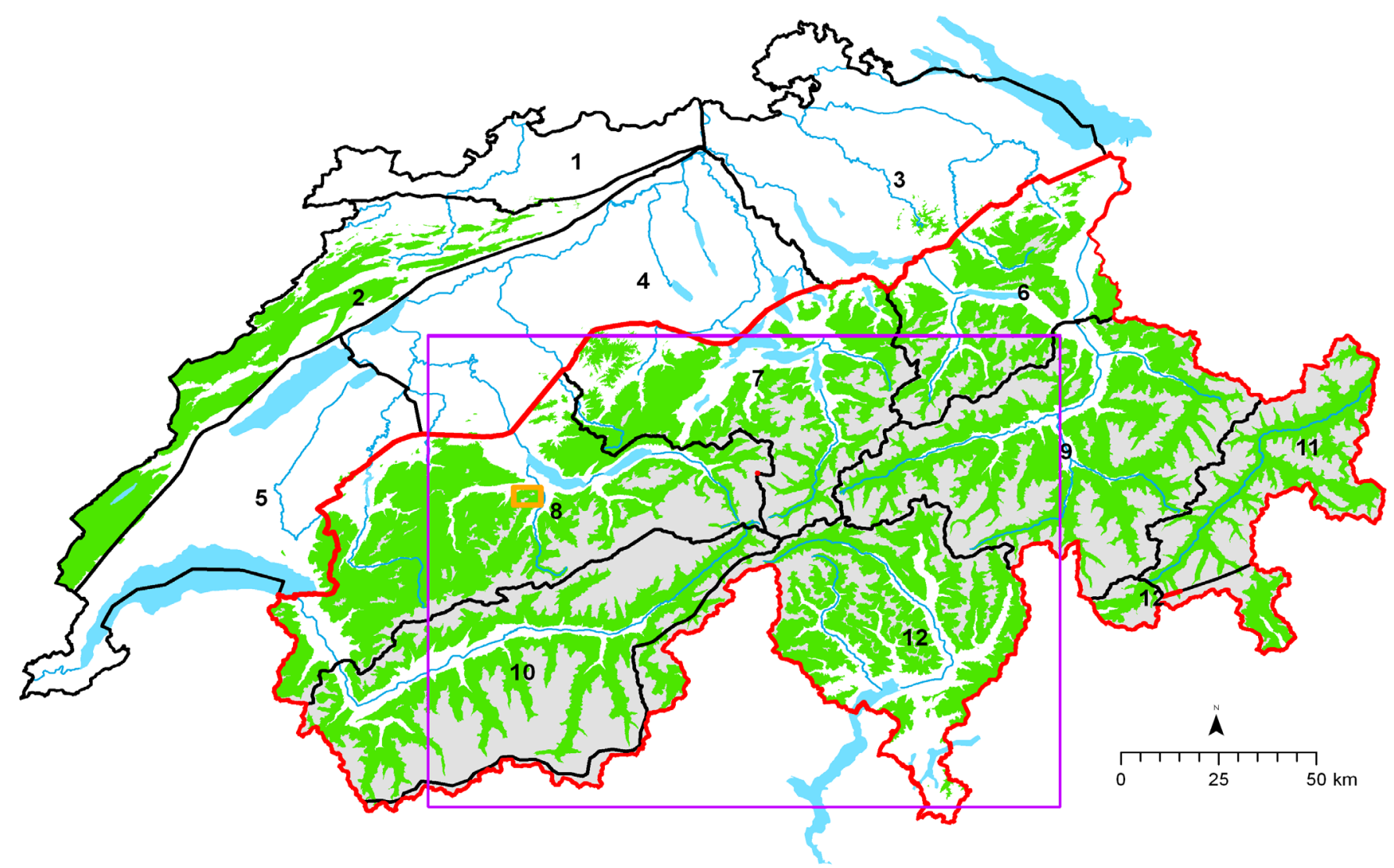

Area above tree line

Area 1000 metres a.s.I.

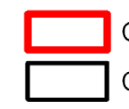
Climatic regions of the Swiss Alps (@ MeteoSwiss) Climatic regions of Switzerland (@ MeteoSwiss)

Study area of Eggenberg (2002)

Niesen

Lakes and rivers (BFS/swisstopo 2009)

Figure 2. The map shows the area exceeding an altitude of 1000 m.a.s.l. (green) and the area above the tree line (grey). The purple box indicates the perimeter of reference data from the study of Eggenberg (2002) (Figs. 10 and 11). The orange box indicates the boundary of Figs. 3, 5, and 6, which show intermediate results of the analysis for the example of Niesen ridge. The red and the black lines delimit the climatic regions by Schüepp \& Gensler (1980) which served as spatial reference units for the explorative analyses. They include: 1 Eastern Jura, 2 Western Jura, 3 North-eastern Swiss Plateau, 4 Central Swiss Plateau, 5 Western Swiss Plateau, 6 Eastern part of the Northern Alps, 7 Central part of the Northern Alps, 8 Western part of the Northern Alps, 9 Northern and central Grisons, 10 Valais, 11 Engadin, 12 Southern Alps. The red line encloses the climatic regions of the Swiss Alps which is the perimeter of Figs. 7, 8, and 9. 
The results of the study by Eggenberg (2002) were used as reference datasets. He recorded the regional maximum altitude of trees and closed forest on 180 test sites based on stereoscopic aerial photographs. Isolines of the regional maximum tree and forest line altitude were derived by linear interpolation for a large part the Swiss Alps. He thus refined the isolines from earlier studies (Brockmann-Jerosch 1919; Landolt 1984). The perimeter is shown in Fig. 2.

\subsection{Preparation of the forest and the tree dataset}

Grom Arealstatistik and Vector25 land cover classes - with trees were extracted and combined to derive both a tree and a forest dataset (Fig. 3).

From Arealstatistik the classes (codes in brackets) normal dense forest (11) and afforestation (9) were included in the forest dataset. From Vector25 the classes closed forest (Z_Wald), and forest on swamp (Z_SumWa) were included.

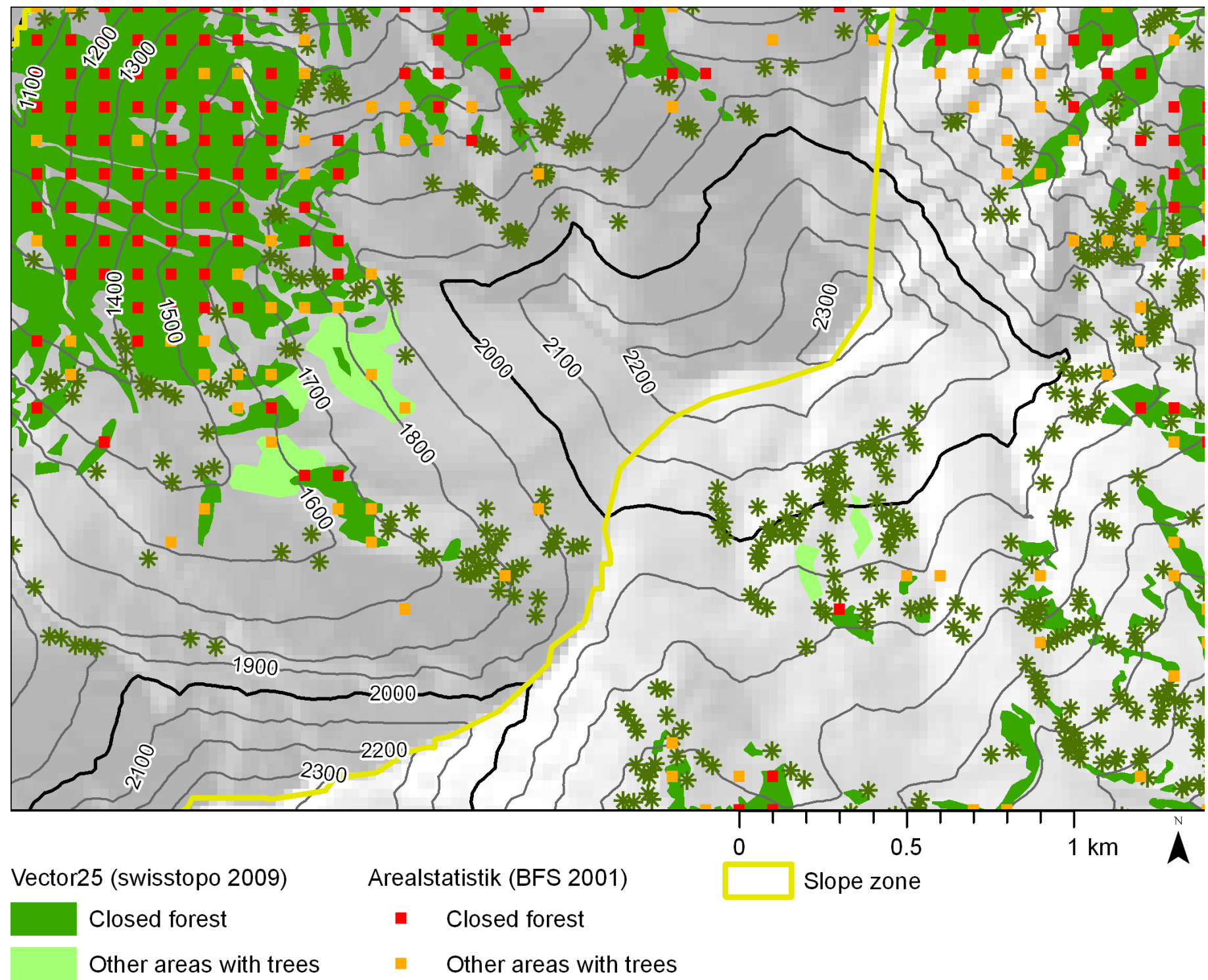

* Single trees

Figure 3. The map shows the forest dataset and the tree dataset according to the sources Arealstatistik 1992-1997 (BFS 2001) and Vector25 (Swisstopo 2009). The yellow line is the boundary of the slope zones which served as spatial reference units for the analysis. The map encloses the Niesen $(2362 \mathrm{~m})$, the first peak of an elongated ridge in the Kandertal. 
From Arealstatistik the following classes were included to the tree datasets (codes in brackets): Normal dense forest (11), afforestation (9), damaged forest area (10), open forest $(12,13)$, brush forest (15), forest strip (14), grove, hedge $(17,19)$, cluster of trees $(18)$, orchard $(75,76,77)$. From Vector 25 the following classes were included to the tree datasets (codes in brackets): Closed forest (Z_Wald), open forest with $<50 \%$ canopy cover (Z_WaldOf), forest on boulder (Z_GerWa), open forest on boulder ( $Z_{-}$GerWaO), forest on swamp ( $Z_{-}$ SumWa), open forest on swamp (Z_SumWaO), single tree (EinBaum, ObstBaum), hedgerow (Hecke), tree line (BauReihe, OBReihe).

Brush meadows and pastures $(84,86)$ and shrub vegetation (16), from Arealstatistik as well as shrub land (Z_Gebue, Z_GerGeb, Z_SumGeb) from Vector25 were excluded as these classes may indicate dwarf shrubs of which some species exceed the tree line.

72 single trees from Vector25 and two sample points from Arealstatistik were excluded from the analyses, as they were obvious errors in the base data. Most of them are located above an altitude of 2300 metres. Besides this, no modification of the base data was undertaken.

\subsection{Delimitation of slope zones}

A reas with a minimum altitude of $1000 \mathrm{~m}$ above Asea level were delimited, using the elevation model DHM25 (Fig. 2). From the resulting 22,557 km² (54.5\% of Switzerland), polygons larger than $4 \mathrm{~km}^{2}$ were included in further analyses.

Slope direction was calculated and classified into four compass directions, North, East, South, and West. A focal majority filter (radius: 75 metres) was applied to simplify the boundaries between the classes. The raster was converted into polygons. To reduce the influence of small geomorphologic elements, polygons smaller than $4 \mathrm{~km}^{2}$ were integrated stepwise into neighbouring areas, starting with the smallest polygons.

The slope polygons were overlaid with the catchment areas (BWG \& GIUB 2001). Cut polygons smaller than $4 \mathrm{~km}^{2}$ were integrated into neighbouring areas. The resulting 2364 polygons have a mean area of $9.5 \mathrm{~km}^{2}$. In the following, they are named slope zones.

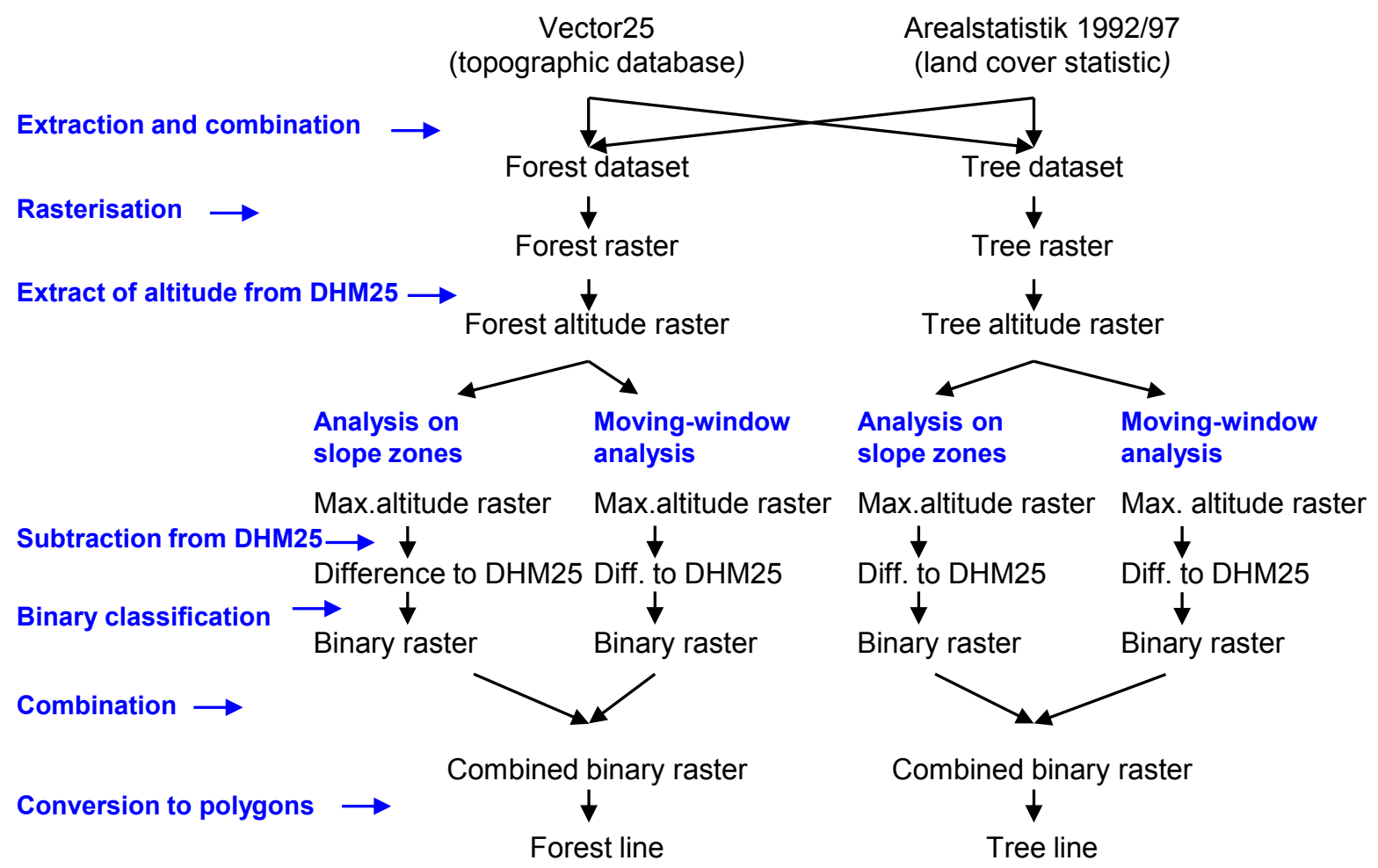

Figure 4. The data flow diagram lists the intermediate products (black) and the processes (blue) of the analysis. The topographic database Vector25 (Swisstopo 2009) and the land cover statistic Arealstatistik 1992-1997 (BFS 2001) served as data sources. The digital elevation model DHM25 (Swisstopo 2001) was used to assign the altitude to the forest and the tree raster cells and to delimit the area above and below the maximum altitude of forest and trees. 


\subsection{Analyses based on slope rones and moving windows}

The moving-window analysis (Tomlin 1990; 1 Danzeglocke 2005) and the analysis on slope zones were performed separately with the forest and the tree dataset. The data flow and the intermediate products of the subsequent procedures are shown in Fig. 4.

Each slope zone was split along the altitude line reached by the uppermost tree and the uppermost forest: Both the tree and the forest datasets were rasterised by $25 \times 25 \mathrm{~m}$ and the altitude was assigned to each cell to derive a tree and a forest altitude raster. For each slope zone, the highest altitudes of trees and forest were recorded and the values were assigned to the whole zone in the two maximum-altitude raster. The maximum-altitude raster were subtracted from the digital elevation model DHM25. The differences were binary classified at the Zero value into an upper and a lower part. For graphical representation in Fig. 5, the raster were converted to maximum-altitude lines.

The analysis on slope zones was extended by a movingwindow analysis: A focal-maximum function with a radius of $1000 \mathrm{~m}$ was applied on both the tree and the

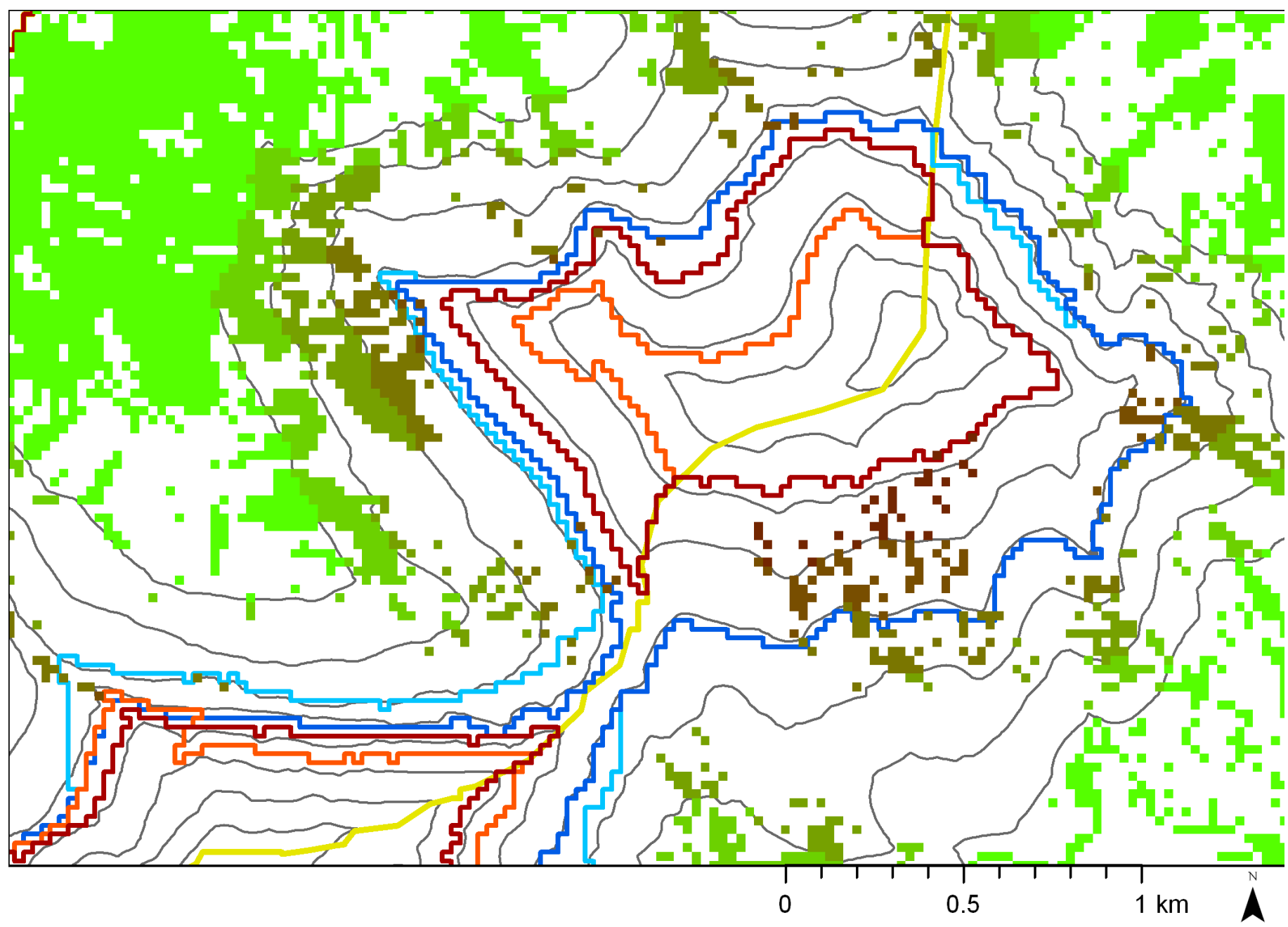

Intermediate maximum-altitude lines

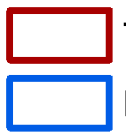
Tree - slope zone
Forest - slope zone

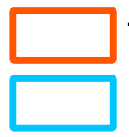
Tree - moving window
Forest - moving window Altitude of trees and forest (m.a.s.I.)

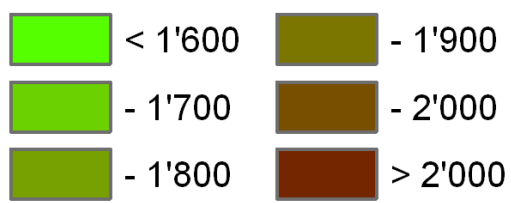

Figure 5. The dark red line indicates the maximum altitude of a tree inside the respective slope zone. The dark blue line shows the same for closed forest. The orange line is the result of the moving-window analysis recording the maximum altitude of a tree in a search radius of $1 \mathrm{~km}$. The light blue line is the result of the moving-window analysis on closed forest. 


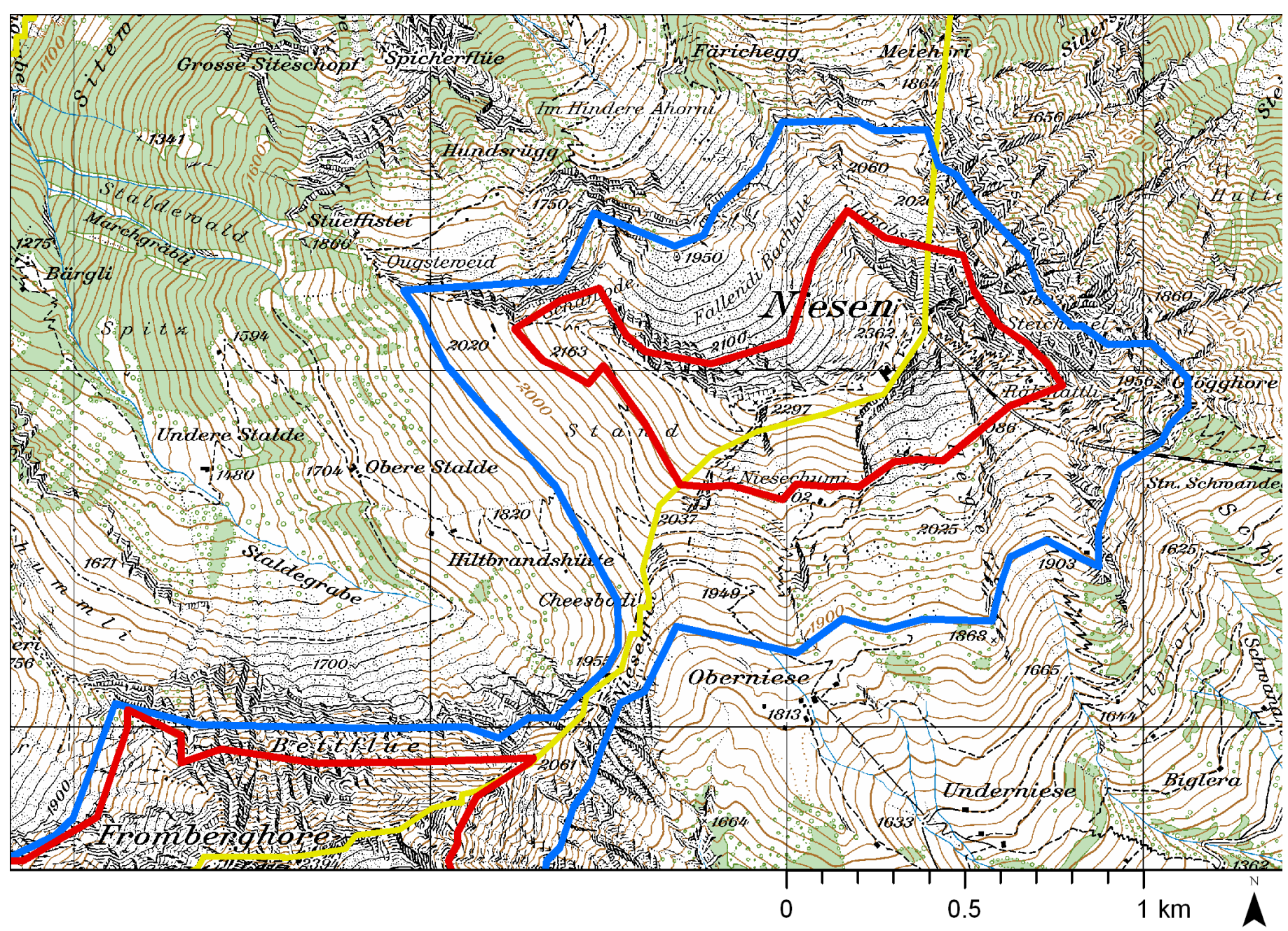

Timber line

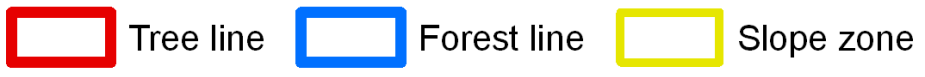

Figure 6. The peak of the Niesen exceeds the tree line by about $240 \mathrm{~m}$ in altitude and with an area of $0.57 \mathrm{~km}^{2}$. The Topographic Map 1:25,000 (2009 (C) Swisstopo) is shown in the background.

forest altitude raster to record the maximum altitude inside each moving window. The window moved cell by cell along each row of the raster. The maximum values were assigned to the centre cell of the moving window and recorded to the resulting maximumaltitude raster.

The maximum-altitude raster were subtracted from the digital elevation model DHM25 and the resulting difference raster were binary classified at the Zero value into an upper and a lower part. The extracted maximum-altitude lines are shown in Fig. 5.

The raster from the analysis on the slope zones and the moving-window analysis were overlaid. If one of both showed that a grid cell is located below the maximum altitude, it was classified as below in the output. The results were converted into polygons (Fig. 6). Polygons smaller than $0.5 \mathrm{~km}^{2}$ were eliminated.

\subsection{Explorative and comparative analyses}

Tntermediate results (Fig. 5) were overlaid to quantify the impact of the two combined approaches on the resulting tree and forest lines: The binary raster of both analyses were converted into polygons and overlaid. Polygons smaller than $650 \mathrm{~m}^{2}$, which is a little larger than the size of a single raster cell, were eliminated as they were considered to be spatial artefacts of the geoprocessing operations. The differences were quantified. 
The range between the maximum altitude of trees and the maximum altitude of forest was calculated for the slope zones: The maximum altitude raster of forest was subtracted from the maximum-altitude raster of trees. The analysis was performed for slope zones which are intersected by both the tree and the forest line.

The isolines published by Eggenberg (2002) were interpolated into elevation models, one for the regional maximum altitude of trees and one for the regional maximum altitude of forest. The resulting maximumaltitude raster were subtracted from the altitudes of the modelled tree lines and forest lines. For the graphic representation in Fig. 10 and Fig. 11 the resulting difference raster were converted into lines.

\section{Results}

The area above the tree line covers $8261 \mathrm{~km}^{2}$ located above the forest line. The zone between the tree line and the forest line covers an area of $1666 \mathrm{~km}^{2}$ (4\%). No tree line was mapped in the Jura Mountains.

In the following, the number codes in brackets indicate the respective climatic region (see Fig. 2 and Tab. 1). Tab. 1, Fig. 7 and Fig. 8 illustrate the effect of mass elevation. The tree and the forest lines rise from the fringes to the higher parts of the Alps. The maximum is reached in the shielded valleys of the Valais (10) and the Engadin (11). The uppermost tree was found at $2485 \mathrm{~m}$ in the valley of S-charl (11). Closed forest was found up to an altitude of $2388 \mathrm{~m}$ near Stalden (10).
In the Engadin (11) the tree line is located at a mean altitude of $2294 \mathrm{~m}$ and the forest line at $2213 \mathrm{~m}$. The standard deviation of $71 \mathrm{~m}$ for the tree line and $68 \mathrm{~m}$ for the forest line is relatively small. In contrast, the gradient is stronger in the side valleys of the Valais (10). The standard deviation is $107 \mathrm{~m}$ for altitude of the tree line and $128 \mathrm{~m}$ for the forest line.

The lowest altitudes of the tree and forest lines can be found on calcareous rock faces in the Northern Alps $(6,7,8)$ starting from $1383 \mathrm{~m}$ and $1314 \mathrm{~m}$ respectively. Compared to the Northern Alps, the tree and the forest lines are higher in the Southern Alps (12) where the tree line is located at a mean altitude of $2142 \mathrm{~m}$ with a standard deviation of $78 \mathrm{~m}$. The mean altitude of the forest line is $1984 \mathrm{~m}$ with a standard deviation of $128 \mathrm{~m}$.

The impact of the analysis on slope zones on the results is stronger than that of the moving-window analysis. On the one hand the analysis on slope zones delimited $399 \mathrm{~km}^{2}$ as below tree line and $502 \mathrm{~km}^{2}$ as below forest line while the moving-window analysis classified these areas as above. On the other hand, the moving-window analysis classified $105 \mathrm{~km}^{2}$ as below tree line and 126 $\mathrm{km}^{2}$ as below forest line while the analysis on slope zones classified these areas as above. At the Niesen (Figs. 5 and 6) the moving-window analysis caused a shift of the tree line on the western slope zone to the same altitude as in the eastern slope zone. For a line segment in eastern direction the search radius of $1000 \mathrm{~m}$ was too short and the shift is smaller. In the eastern slope zone the lines almost cover each other.

Table 1: The altitudes of the tree line and forest line were determined for the major climatic regions of Switzerland in m. a. s. 1..

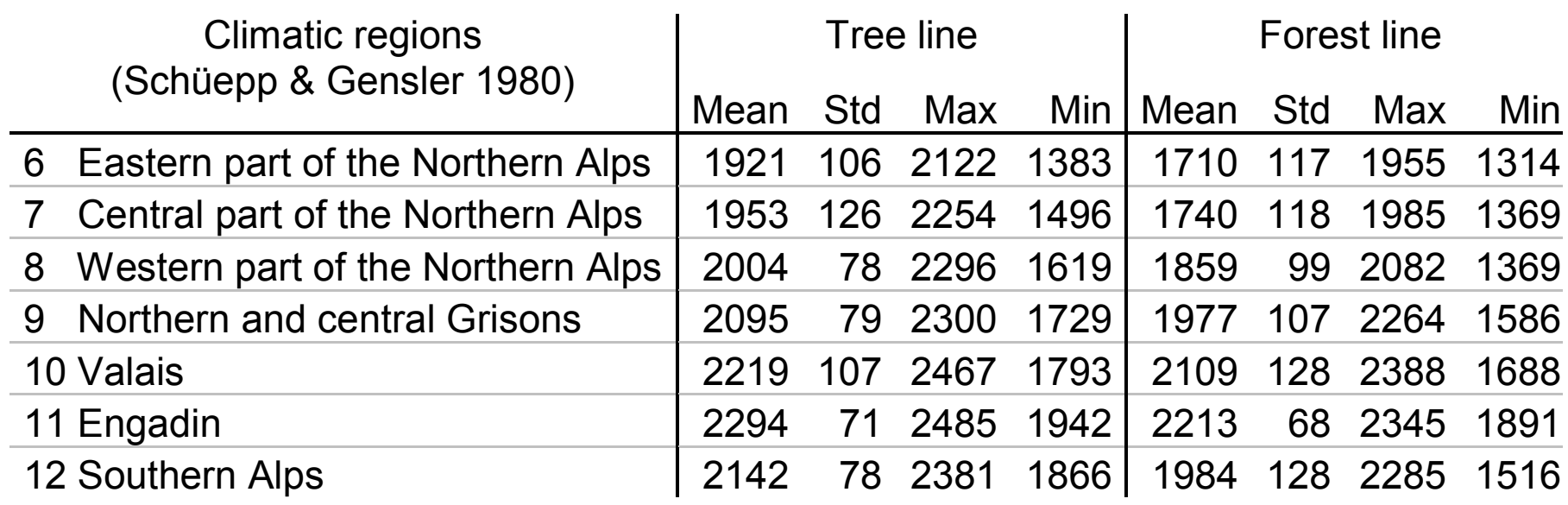




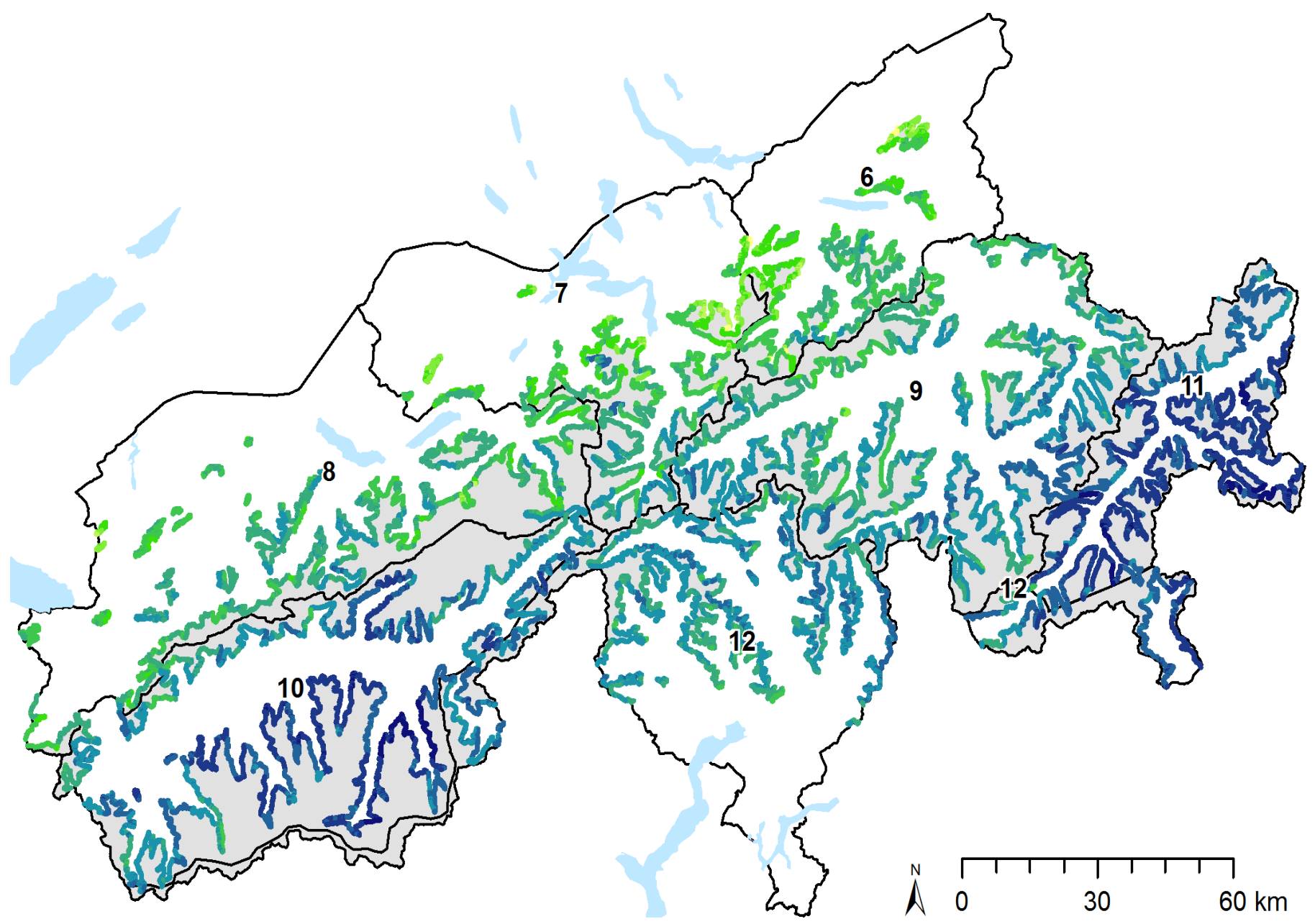

Tree line altitude based on Vector25 and Arealstatistik
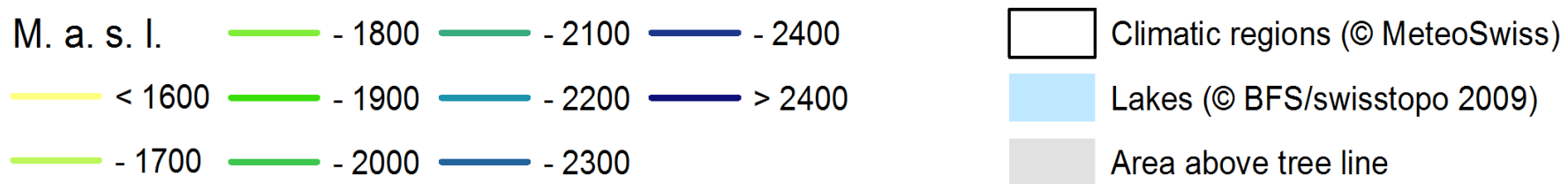

Figure 7. The tree line altitude is shown in categories. It rises from the isolated peaks and ridges to the shielded side valleys of the Valais (10) and the Engadin (11).

Fig. 9 indicates large regional differences in the altitudinal range between the uppermost trees and the uppermost forest. The eastern part (6) and the central part (7) of the Northern Alps and especially the northern Gotthard region show slope zones with high ranges. In regions with a high tree line $(10,11)$, the ranges are relatively small. The mean range in 1430 slope zones is 135 metres. The median is 115 metres.

Fig. 10 and Fig. 11 show the regional variability of the tree and the forest line altitude. The mean deviation of the modelled tree line from the regional maximum of tree line altitude given by Eggenberg (2002) is -17.2 $\mathrm{m}$ (Fig. 10). $45 \%$ of the tree lines exceed the altitude values of Eggenberg (2002) with a mean deviation of 49.3 metres. The mean deviation of the tree line located below is -71 metres. The mean deviation of the modelled forest line from the regional maximum of forest line altitude (Eggenberg 2002) is -68 metres. $27 \%$ of the forest lines exceed the values of Eggenberg (2002) with mean deviation of 42 metres. The mean deviation of the forest line below is -110 metres. In general, the deviation of the forest line is larger than of the tree line. 


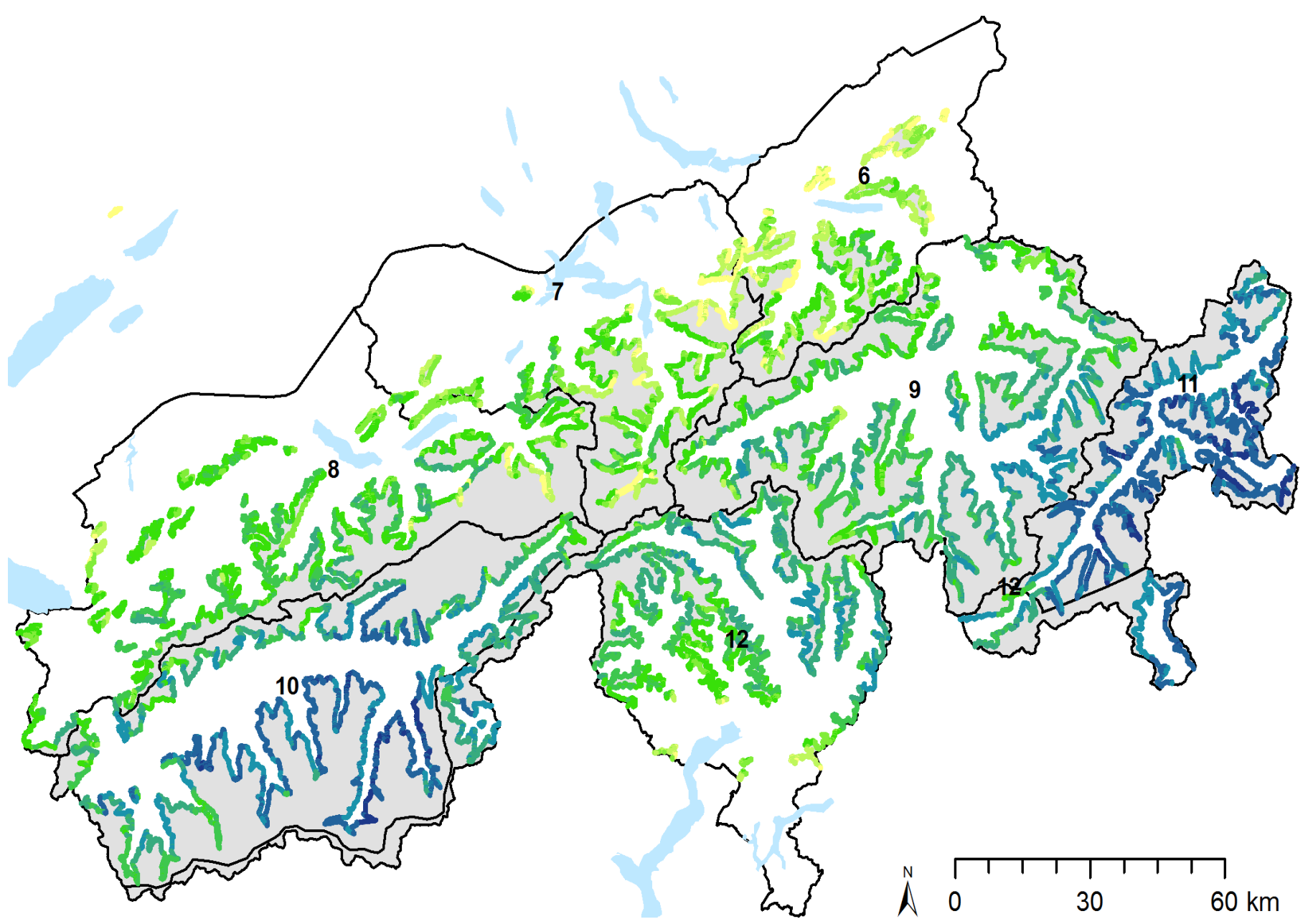

Forest line altitude based on Vector25 and Arealstatistik

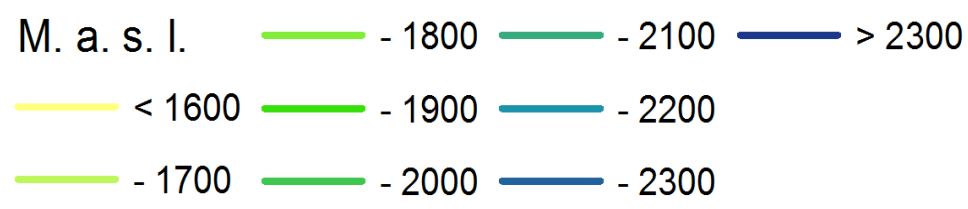

Climatic regions (@ MeteoSwiss)

Lakes (@ BFS/swisstopo 2009)

Area above forest line

Figure 8: The forest line altitude is shown in categories. It rises from the isolated peaks and ridges to the shielded side valleys of the Valais (10) and the Engadin (11).

\section{Discussion}

$\mathrm{T}$ he GIS analyses allowed delimiting plausible and reproduceable tree and forest lines, for the first time for all of Switzerland. The presented model can be implemented in a standard GIS. The setting will calculate on a standard PC in a few hours. The technical accuracy depends on the accuracy of the base data and the applied raster resolution. In this case, the geometric error was estimated to be less than 50 metres. On steep rock faces the overlap of rock signatures and single trees required generalisation of the topographic map. In extreme cases, this can result in an altitudinal deviation of about one hundred metres.

The delimitation of the spatial reference units for measuring tree and forest line altitude is a crucial point in the methodology. Besides the impact of the regional climate it is necessary to decide whether or not to respect local geologic and topographic conditions. Paulsen \& Körner (2001) applied a regular $10 \times 10 \mathrm{~km}$ grid on Arealstatistik 1979-1985 (BFS 1985). They calculated tree line altitude based on the uppermost tree in each grid cell. This created difficulties for further modelling, since the grid ignored the topographic conditions. 


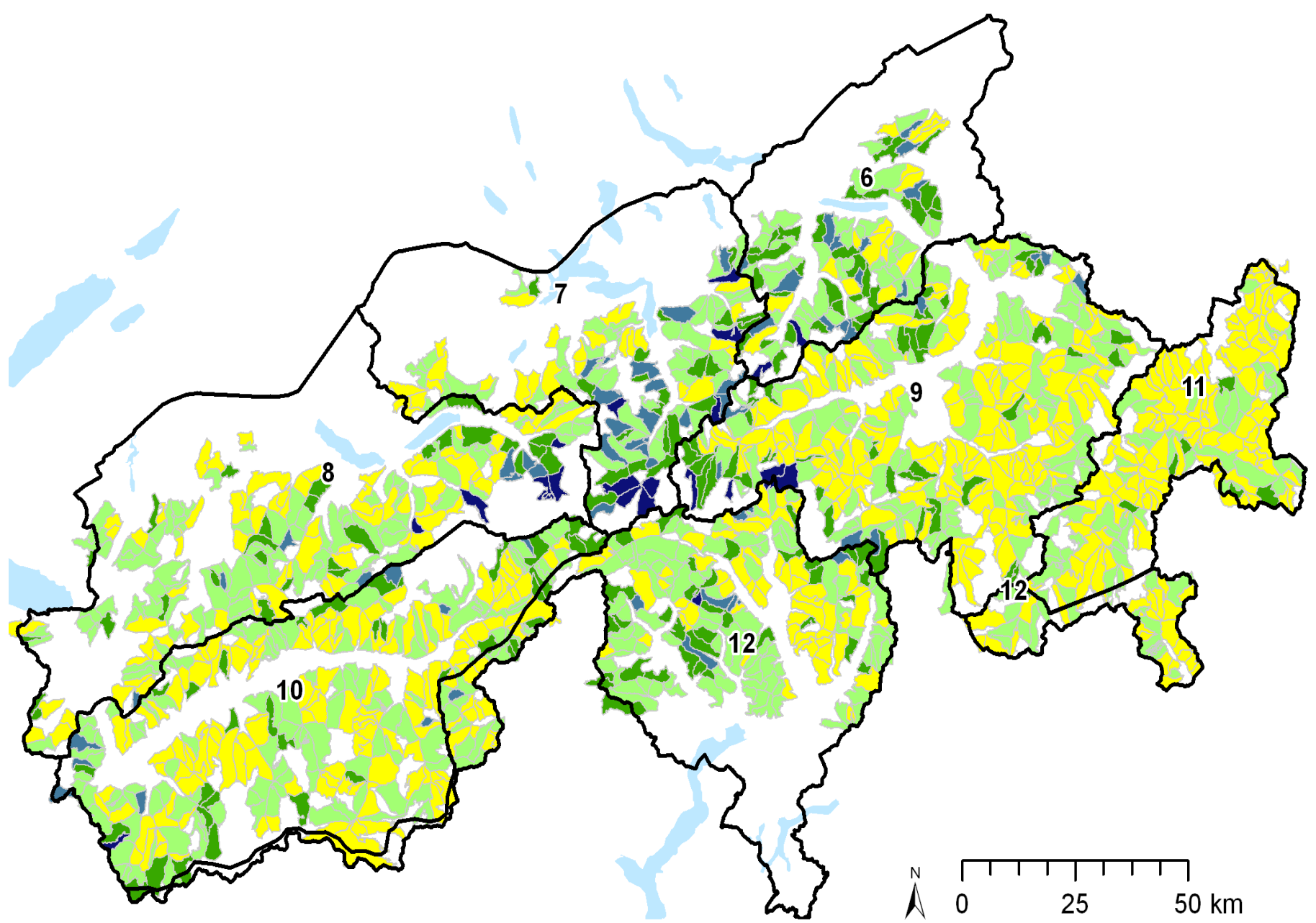

Altitudinal range between the uppermost forest and the uppermost tree inside the slope zones (in metres)

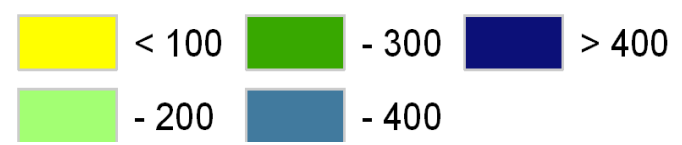

Climatic regions (@ MeteoSwiss)

Lakes (BFS/swisstopo 2009)

Figure 9. The altitudinal range between the uppermost tree and the uppermost forest was calculated and coloured by slope zones. Only slope zones were considered which are crossed by both the tree and the forest line.

The slope zones applied here represent topographic meaningful reference units and the moving-window analysis focus on local conditions. The combination of both approaches improved the shape of the delimitation. The analysis on slope zones delivered feasible results on wide, plane valley slopes while the moving-window analysis improved the results on slope zones with a short horizontal extent.

Both approaches are size dependent. The search radius of $1000 \mathrm{~m}$ for the moving-window analysis was defined short enough not to reach over significant ridges, whereas on wide, plane, and managed valley slopes it is too short to delimit the targeted altitude line consistently. Eggenberg (2002) recommended 30 $\mathrm{km}^{2}$ as the optimal size for the spatial reference units to assess the altitude of the potential tree line. This corresponds well to the catchment areas with a size ranging between $30-50 \mathrm{~km}^{2}$ (BWG \& GIUB 2001). Catchment areas are a useful basis, since they reflect topographic conditions. Preliminary tests showed that the results were consistent on homogenous valley slopes, whereas in regions with changing relief they were often hard to explain. A minimum size of $4 \mathrm{~km}^{2}$ and a mean size of $9.5 \mathrm{~km}^{2}$ delivered feasible results. 


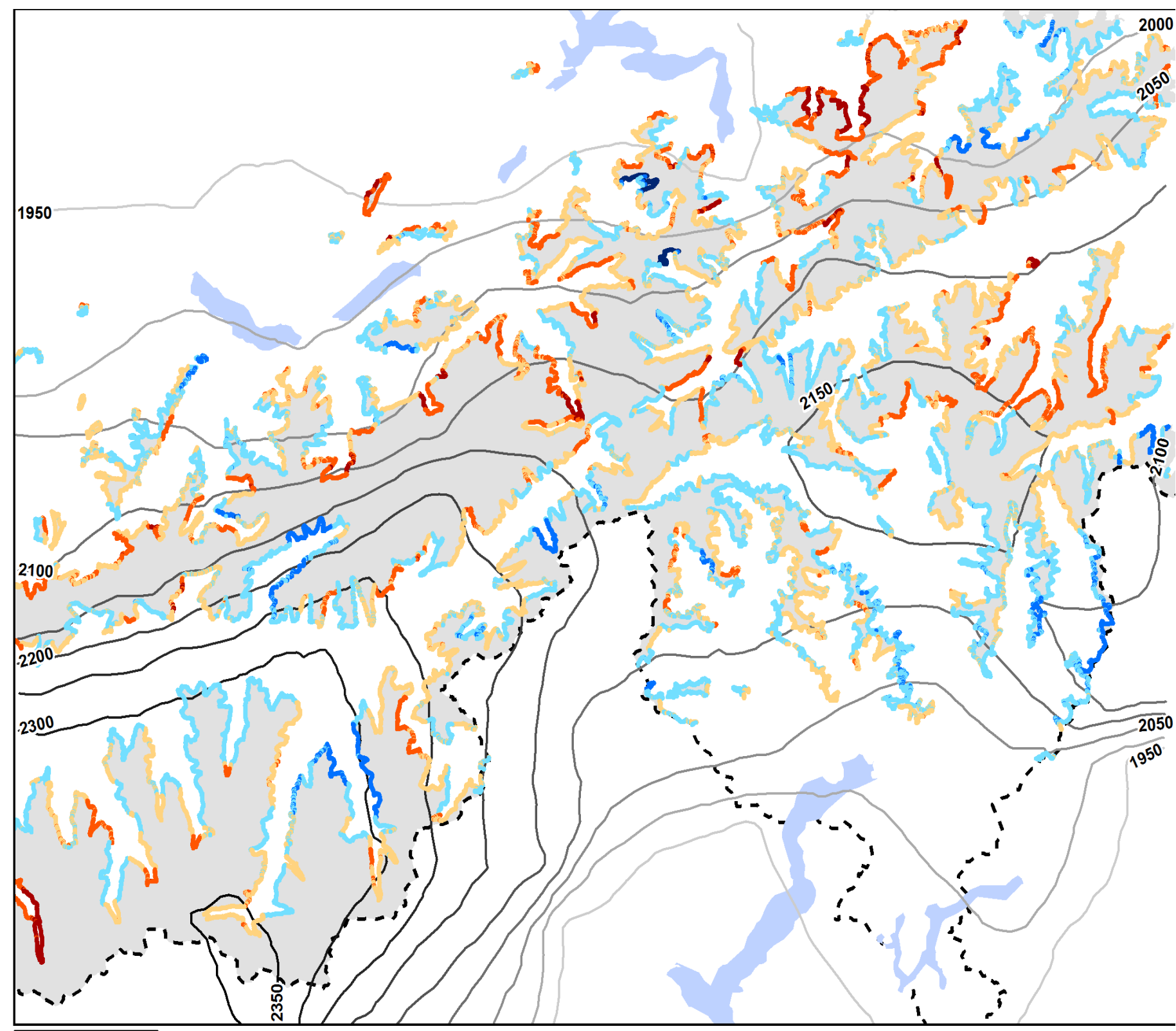

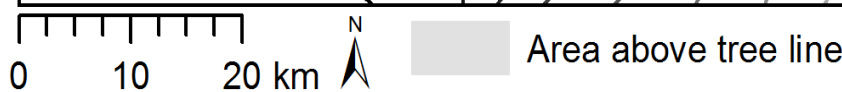

Lakes (@ BFS/swisstopo 2009) - - - - Swiss border

Tree line altitude compared to the regional maximum values of Eggenberg (2002) - difference in metres

Isolines of the regional maximum altitude of trees (Eggenberg 2002) - m.a.s.I.

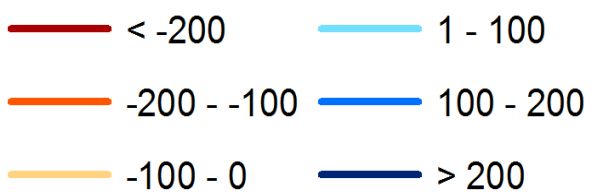

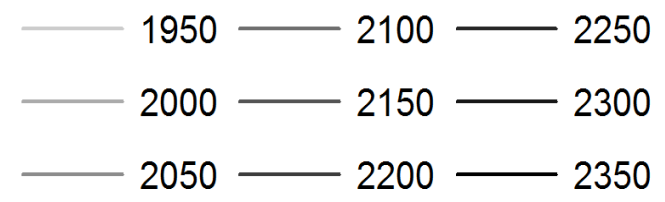

Figure 10. The red lines indicate that the modelled tree line is lower than the regional maximum altitude of trees derived from the isolines given by Eggenberg (2002). The blue lines indicate that the modelled tree line is higher than the regional maximum. 


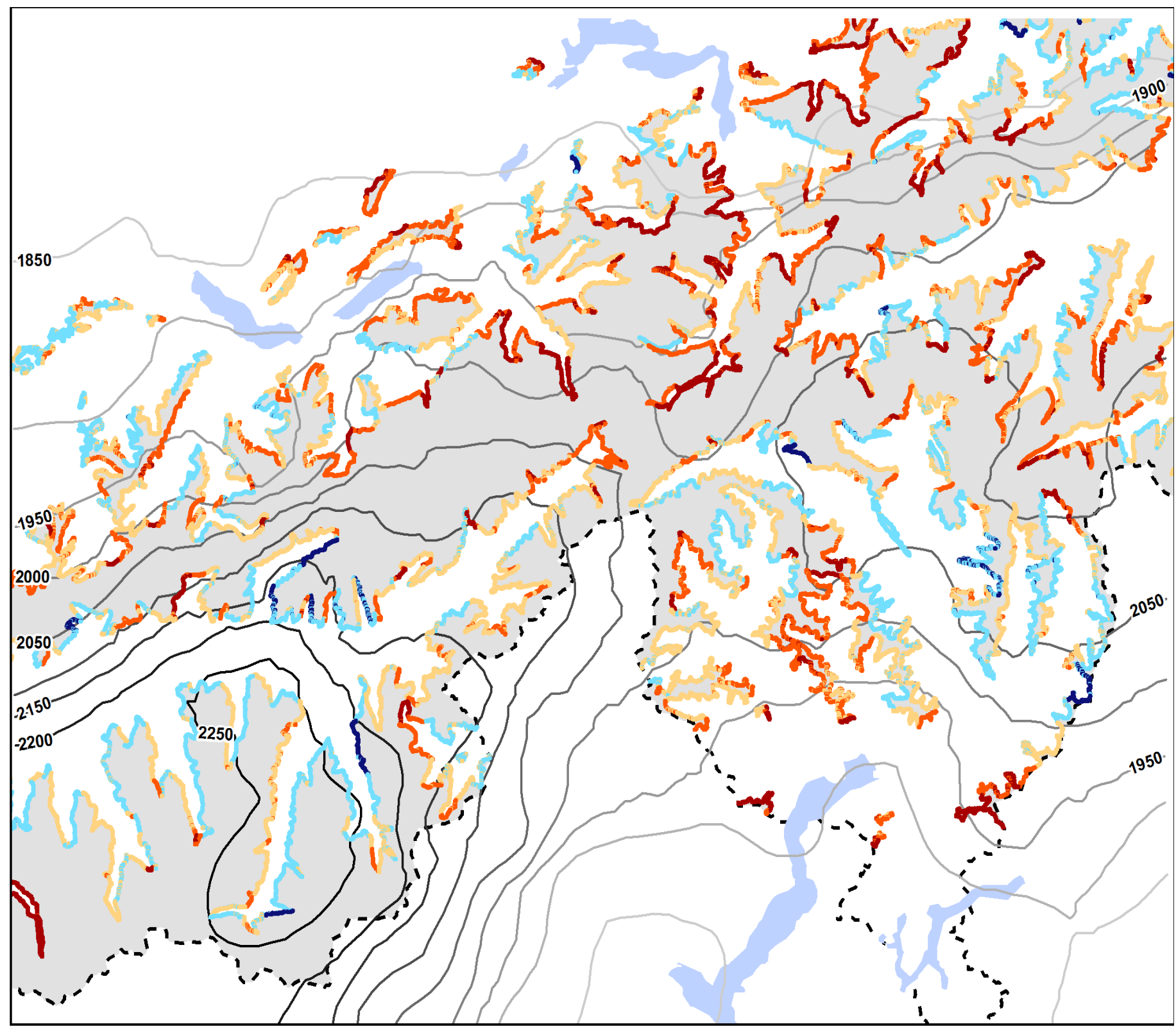

\begin{tabular}{ll|l|l|l|l}
$\Gamma$ & 10 & $N$ & $\mathrm{~N}$ & Area above forest line
\end{tabular}

Lakes (@ BFS/swisstopo 2009) - - - - Swiss border

Forest line altitude compared to the regional maximum values of Eggenberg (2002) - difference im metres

Isolines of the regional maximum altitude of closed forest (Eggenberg 2002) - m.a.s.I.
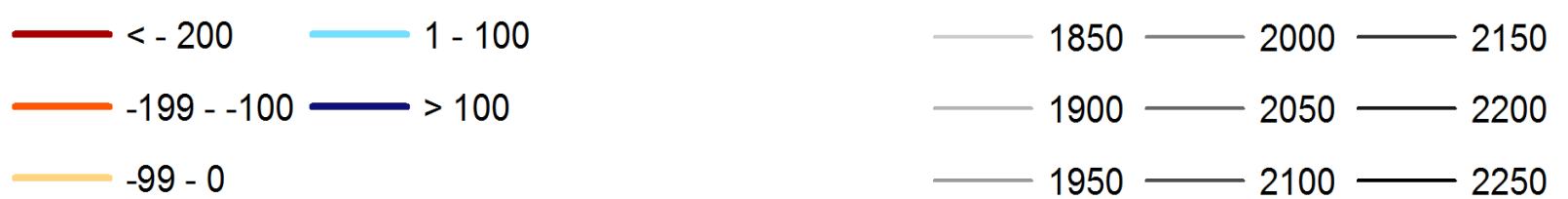

Figure 11. The red lines indicate that the modelled forest line is located lower than the regional maximum altitude of forest derived from the isolines given by Eggenberg (2002). The blue lines indicate that the modelled forest line is higher than the regional maximum. 
The combination of the approaches enabled to calculate with a short radius in the moving-window analysis and with small slope zones. This helped to limit the influence of anthropogenic use on the delimitation on the one hand and to enhance the sensitivity of the analysis to local conditions on the other hand.

Brockmann-Jerosch (1919) reported the range of the maximum-values of tree line altitude with 675 metres, starting from Säntis at $1725 \mathrm{~m}$ in the Northern Alps to $2400 \mathrm{~m}$ in the southern Valais. Hess et al. (1967) specified the upper limit of the subalpine zone for the Central Alps (Valais and Engadin) between 1900 and 2400 metres. The mean altitude values of this study fit into the span but the extreme values deviate. Especially for the Northern Alps it is difficult to set general thresholds. A span of 1700 to $1900 \mathrm{~m}$ as given by Hess et al. (1967) is too narrow, even if applied on the potential tree line. The regions in the Northern Alps show a large topographic and climatic variability and the trees frequently exceed $2000 \mathrm{~m}$ on shielded slopes. For the Jura Mountains, Hess et al. (1967) indicated 1500 to $1700 \mathrm{~m}$ as upper limit of the subalpine zone. But in this study no tree line was mapped in this area. In the Jura Mountains forest grows up to the highest ridges at 1700 metres. Tree growth is only locally limited at single peaks and ridges with extreme climatic conditions, or in sinks (e. g. dolines) at high altitude where cold air accumulates. The Southern Alps, when delimited as Climatic region, reach further northwards than they do in many other geographic classifications. But despite this, 1800 to $2000 \mathrm{~m}$ for the lower limit of the alpine zone as specified by Hess et al. (1967) is too low. The tree line altitudes are generally underestimated for the fringes of the Alps.

The overlay of the results of this study with the regional maximum tree and forest line altitudes by Eggenberg (2002) reflects the soundness of the applied method and the quality of the results. The results correspond well to the altitude values by Eggenberg (2002) as the mean deviation is -17 metres for the forest line and $-68 \mathrm{~m}$ for the tree line. The maximum values match well to where Eggenberg (2002) found the most elevated tree. In this study the most elevated tree inside the comparison area was found a few kilometres away in the same valley. The relatively high tree line in Lötschental, a side valley of the Valais, looks like an outlier at first sight, but actually corresponds to what was found by Brockmann-Jerosch (1928). Most of the deviations can be explained by differences in the methodology. Eggenberg (2002) measured precisely using stereoscopic aerial photographs but as he already mentioned, the number of 180 test areas is insufficient for an interpolation into a large heterogeneous area. Some of the local maximum values are missing. Additionally, the values are smoothed by double interpolation, first from the test sites to the isolines and second to an elevation model. This has amplified the differences in the overlay with the results of the presented model. Using topographic data is less accurate at the single plot but due to the area-wide availability it is sensitive to local conditions. Downward outliers are caused by local geologic and topographic conditions and in some cases by extensive agricultural use.

Paulsen \& Körner (2001) recorded the potential tree line at an altitude between $1750 \mathrm{~m}$ and $2350 \mathrm{~m}$ analysing Arealstatistik 1979-1985 (BFS 1985). GehrigFasel et al. (2007) found the tree line ranging between 1650 and $2450 \mathrm{~m}$, applying the same method and using the next survey of Arealstatistik from 1992-1997 (BFS 2001). The maximum values are lower than what was found in this study for the tree line when combining Arealstatistik with Vector 25 providing single trees as point features.

The altitudinal range between the uppermost tree and the uppermost forest was $100 \mathrm{~m}$ or less in most test sites of Eggenberg (2002). The ranges found in this study show regional differences but in most slope zones the ranges are only slightly larger. Therefore it might be concluded that the definitions of tree and forest used for the survey of the base data are suitable for the needs. The larger ranges can be explained by the smaller spatial reference units used in this study which are more sensitive to local factors. Local environmental conditions like rock faces and soil quality can prevent the growth of closed forest. E.g. Karst formations on calcareous bedrock have a big influence in parts in the Northern Alps. In addition the pressure of agriculture on the forest line is stronger than on the tree line. Single trees are traditional landscape elements on pastures, as they give shelter and shadow. On abandoned land succession stages like shrub land and open forest establish first. Due to the low rates of tree growth the succession to closed forest may take decades. 


\section{Conclusions}

T he study delivered a fine-scaled, GIS-compliant delimitation of the tree and the forest line for Switzerland. The overlay of the results with the regional maximum altitudes by Eggenberg (2002) suggests that the resulting tree line approximate the potential tree line with respect to local geologic and topographic conditions. The deviation of the resulting forest line from the potential forest line is larger by trend.

The advantage of the methodology is that the model can be run over large areas without repeated subjective decisions. By the combination of a moving-windows analysis and an analysis based on slope zones the impact of anthropogenic use on the delimitation could be limited. In summary, this approach is feasible for a rapid assessment of the tree and the forest line if appropriate base data are available.

The results can support the implementation of agrienvironmental measures (BAFU \& BLW 2008) for which relevant spatial units need to be obtained. Furthermore, they are of value for forestry, nature conservation and spatial planning, e.g. the development of ski resorts and built-up areas. Before the practical application, a revision of the results on a local scale is needed. In a modified version the forest line was integrated in the Agricultural landscape types of Switzerland (Szerencsits et al. 2009).

The spatial data of the tree and the forest line are provided for download on http:/ / www.agrarlandschaft. $\mathrm{ch} /$.

\section{Acknowledgement}

$\mathrm{I}$ am grateful to Urs Beat Brändli, Stefan Eggenberg, Andreas Grünig, Felix Herzog, Gabriela Hofer, Manuel Schneider, Beatrice Schüpbach, Thomas Walter, and Michael Winzeler for fruitful discussions on the methodology and the results. Regula Wolz helped with linguistic improvements, and two anonymous reviewers applied valuable criticism to improve the manuscript. The model was developed in the framework of the Swiss landscape typology partly funded by the Federal Office for Spatial Development and the Federal Office for the Environment.

\section{References}

BAFU \& BLW 2008. Umweltziele Landwirtschaft. Hergeleitet aus bestehenden rechtlichen Grundlagen. Umwelt-Wissen Nr. 0820. Federal Office for the Environment, Bern, 221.

Baur, P.; Bebi, P.; Gellrich, M. \& G. Rutherford, 2006. WaSAlp - Waldausdehnung im Schweizer Alpenraum. Eine quantitative Analyse naturräumlicher und sozio-ökonomischer Ursachen unter besonderer Berücksichtigung des Agrarstrukturwandels. Schlussbericht. Birmensdorf, Swiss Federal Research Institute for Forest, Snow and Landscape (FSL), 65 pp.

Bätzing, W. 2005. Die Alpen, Geschichte und Zukunft einer europäischen Kulturlandschaft. C.H. BeckVerlag, München, 231.

BBL 2009. Weiterentwicklung des Direktzahlungssystems: Bericht des Bundesrates in Erfüllung der Motion der Kommission für Wirtschaft und Abgaben des Ständerates vom 10. November 2006 (06.3635), Bern.

BFS 1985. Arealstatistik 1979-1985. GEOSTAT, Swiss Federal Statistical Office, Neuchâtel.

BFS 2001. Arealstatistik 1992-1997. GEOSTAT, Swiss Federal Statistical Office, Neuchâtel.

Brockmann-Jerosch, H. 1919. Baumgrenze und Klimacharakter. Beiträge zur geobotanischen Landesaufnahme 6. Zurich, 255.

Brockmann-Jerosch, H. 1928. Meereshöhen der Baumgrenze in der Schweiz (Map of climatic treeline elevations in Switzerland) $1: 600$ 000. Kümmerly \& Frey, Bern.

Burga, C. A.; Klötzli, F. \& G. Miehe, 2004. Waldgrenze: Phänomen und globaler Vergleich. In: Burga, C. A., Klötzli, F. \& G. Grabherr (eds.) Gebirge der Erde. Landschaft, Klima, Pflanzenwelt. Ulmer, Stuttgart, $20-21$.

BWG \& GIUB 2001. Hydrographische Gliederung der Schweiz. GEOSTAT, Swiss Federal Statistical Office, Neuchâtel.

Danzeglocke, J. 2005. Remote sensing of upper timberline elevation in the Alps on different scales. 
In Oluic'M. New Strategies for European Remote Sensing. Millpress, Rotterdam, 145-151.

Dirnböck, T., Dullinger, S. \& G. Grabherr 2003. A regional impact assessment of climate and land-use change on alpine vegetation. Journal of Biogeography, 30, 401-417.

Dullinger, S., Dirnböck, T., Greimler, J. \& G. Grabherr 2003. A resampling approach for evaluating effects of pasture abandonment on subalpine plant species diversity. Journal of Vegetation Science 14, 243-252.

Eggenberg, S. 2002. Die Waldgrenzvegetation in unterschiedlichen Klimaregionen der Alpen. Cramer; Berlin, Stuttgart, 157.

Ellenberg, H. 1986. Vegetation Mitteleuropas mit den Alpen in ökologischer Sicht. Ulmer, Stuttgart, 989.

Gehrig-Fasel, J., Guisan, A. \& N.E. Zimmermann 2007. Treeline shifts in the Swiss Alps: climate change or land abandonment? Journal of Vegetation Science 18, 571-582.

Hess, H. E., Landolt, E. \& R. Hirzel 1967. Flora der Schweiz und angrenzender Gebiete. Band I: Pteridophyta bis Caryophyllaceae. Birkhäuser, Basel und Stuttgart, 858.

Holtmeier, F.K. 2009. Mountain Timberlines: Ecology, Patchiness, and Dynamics. Springer-Verlag. Berlin, 437.

Holtmeier, F.K. \& G. Broll 2007. Treeline advanceDriving processes and adverse factors. Landscape Online 1, 1-33.

Hotz, M.C. \& F. Weibel 2005. Wald und Gehölze. In Arealstatistik Schweiz: Zahlen - Fakten - Analysen. Bundesamt für Statistik, Neuchâtel, 64-76.

Hunziker, M. 1995. The spontaneous reafforestation in abandoned agricultural land: perception and aesthetic assessment by locals and tourists. Landscape and urban planning 31, 399-410.

Imhof, E. 1900. Die Waldgrenze in der Schweiz. Sonderabdruck aus Gerland's Beiträgen zur Geophysik 4/3, Wilhelm Engelmann, Leipzig, 330.

Körner, C. 2003. Alpine plant life: functional plant ecology of high mountain ecosystems. SpringerVerlag. Berlin, 347.

Kruckeberg, A.R. 2002. Geology and plant life: The effects of land forms and rock types on plants. University of Washington Press, Seattle, 362.

Landolt, E. 1984. Unsere Alpenflora. Verlag SAC, 318.

Mack, G., Walter, T. \& C. Flury 2008. Entwicklung der Alpung in der Schweiz: Ökonomische und ökologische Auswirkungen. Yearbook of Socioeconomics in Agriculture 2008, 259-300.

Paulsen, J. \& C. Körner 2001. GIS-analysis of tree-line elevation in the Swiss Alps suggests no exposure effect. Journal of Vegetation Science 12, 817-824.

Schmid, E. 1961. Erläuterungen zur Vegetationskarte der Schweiz. Beiträge zur geobotanischen Landesaufnahme der Schweiz Heft 39, Verlag Hans Huber, Bern, 52.

Schüepp, M. \& G. Gensler 1980. Klimaregionen der Schweiz. In Müller, G. 1980. Die Beobachtungsnetze der Schweizerischen Meteorologischen Anstalt. Konzept 1980. Arbeitsberichte der Schweizerischen Meteorologischen Anstalt, Nr. 93, Anhang Ib. Zurich.

Swisstopo 2001. DHM25, digital height model $25 \times 25 \mathrm{~m}$ DV002207.1. Swiss Federal Office of Topography, Bern.

Swisstopo 2009. Vector25, digital landscape model. DV002208.2 Swiss Federal Office of Topography, Bern.

Swisstopo 2011. Siegfried Karte, topographischer Atlas der Schweiz 1:50,000. http://www.swisstopo.admin. $\mathrm{ch} /$ internet/swisstopo/de/home/products/maps/ hist.html (Date: 30.08.2011).

Szerencsits, E., Schüpbach, B., Conradin, H., Grünig, A. \& T. Walter 2009. Agrarlandschaftstypen der Schweiz. ART-Berichte Nr. 712 Agroscope Reckenholz-Tänikon ART, Zurich.

Tomlin, C.D. 1990. Geographic Information Systems and Cartographic Modelling. Prentice-Hall, Englewood Cliffs, US.

Wardle, P. 1974. Alpine timberlines. In: J.D. Ives \& R. Barry. Arctic and alpine environments. London, 371-402.

Welten, M. \& R. Sutter 1982. Verbreitungsatlas der Farn- und Blütenpflanzen der Schweiz. Birkhäuser, Basel. Bd. 1: 716 S.; Bd. 2, 698. 
Wieser, G. \& M. Tausz 2007. Current concepts for Treelife Limitation at the Upper Timberline. In Wieser, G. \& M. Tausz 2007. (eds.) Trees at their Upper Limit - Treelife Limitation at the Alpine Timberline. Springer, 1-18.

Wohlgemuth, T. 1993. Der Verbreitungsatlas der Farn- und Blütenpflanzen der Schweiz (Welten und Sutter 1982) auf EDV. Die Artenzahlen und ihre Abhängigkeit von verschiedenen Faktoren. Bot. Helv. 103, 55-71. 